\title{
DOSSIÊ \\ Violência, Guerra e Migração no Mundo Antigo
}





\section{Apresentação}

Estefanía Bernabé-Sánchez*

Katia Maria Paim Pozzer*

Pedro Paulo A. Funari ${ }^{* * *}$

Se fosse preciso definir com três conceitos-chave a conjuntura deste primeiro quarto de século XXI, os organizadores deste dossiê acreditam que a maioria dos questionados conviria em utilizar, pelo menos, alguma das palavras que propomos como título. A ideia, então, de organizar um volume sobre a temática da guerra, da violência e da migração no mundo antigo nasce, simplesmente, de nossa observação da realidade contemporânea. Impotentes como historiadores, professores e/ou seres humanos, assistimos à eclosão de conflitos militares de rara violência na região do Oriente Próximo que atingem o planeta inteiro. A guerra na Síria, a ofensiva do autointitulado Estado Islâmico, a invasão do Iraque pela chamada "coalizão internacional”, liderada pelos EUA, trouxeram enorme instabilidade política e, mais importante, uma tragédia humanitária sem precedentes na história recente. Não podemos esquecer a outra face das guerras, tão dramática quanto a primeira, que representa as migrações forçadas de milhares de pessoas. Tudo isso, associado à destruição, ao espólio e ao saque do patrimônio cultural da humanidade presente nesses territórios, teve um efeito provocador a nós, historiadores da antiguidade.

"Professora da Pontificia Universidad Católica del Peru - PUCP. E-mail: e.bernabe1976@gmail.com.

Professora da Universidade Federal do Rio Grande do Sul - UFRGS. E-mail: katia.pozzer@ufrgs.br.

Professor da Universidade Estadual de Campinas - UNICAMP. E-mail: ppfunari@uol.com.br. 
Nosso dever de ofício aceita como tarefa primordial, então, o fato de tentarmos entender o mundo que hoje nos cerca estabelecendo um diálogo entre passado e presente, se quisermos construir o melhor futuro possível. Eis aí, para nós, a pedra fundamental do conhecimento e do estudo da antiguidade. Mais do que nunca, faz-se necessário propor o debate, instigar a pesquisa, incitar a reflexão construtiva como nossa contribuição para a sociedade. E assim, algumas indagações nortearam nossa proposição. É possível tirar lições do passado? Somos capazes de compreender o conflito como fato e suas diversas dimensões na antiguidade e na atualidade, para estabelecermos paralelismos válidos e evitá-los, no futuro?

A partir dessas questões, formulamos a proposta do dossiê Violência, Guerra e Migração no Mundo Antigo, com o objetivo de refletir sobre temas urgentes e atuais a partir do estudo das sociedades antigas. Sabemos que as práticas de violência legitimadas pelas guerras, tendo como consequência a migração massiva de populações, têm uma longa historicidade, pois essas diversas experiências históricas foram preservadas e deixaram inúmeros indícios nos textos, nas imagens e na cultura material. Assim, entendemos que investigar essa temática na antiguidade pode contribuir para a compreensão dos recentes acontecimentos que atingem o mundo, especialmente o Mediterrâneo, a Europa e os EUA.

O enunciado deste dossiê abraça, entretanto, diversos outros enfoques, tais como questões relacionadas à tecnologia da guerra, à retórica da violência, à situação das mulheres e crianças nos conflitos, às agressões sexuais, à migração e ao fenômeno de transculturação, entre outros. Como afirma Magnoli (2006, p. 14): "A guerra é um fenômeno total, uma expressão condensada das formas de pensar, produzir e consumir das sociedades, o espelho de um tempo e um lugar".

Foram vários os autores que atenderam ao nosso chamado. Eles provêm de distintos horizontes de pesquisa, alguns atuando no Brasil e outros no exterior. Vários são especialistas no Mundo Clássico, enquanto outros se interessam pelo Oriente, mas todos aportam uma reflexão original e uma boa dose de erudição.

O dossiê abre com a contribuição de Pedro Paulo A. Funari, intitulada "Migration flows from a long-term perspective", que 
traz um estudo de longa duração sobre o fenômeno das migrações na história da humanidade. $\mathrm{O}$ autor discute os fluxos migratórios desde o processo de hominização até o período pós-segunda guerra mundial, incluindo a história brasileira, e argumenta que as migrações são um grande desafio tanto para as sociedades como para os intelectuais que refletem sobre elas.

A professora Katia Maria Paim Pozzer contribui com "Guerra, violência e memória cultural nas imagens assírias”, artigo no qual faz partir sua reflexão dos baixos-relevos em pedra resgatados dos palácios assírios de Nínive, analisando alguns elementos estéticos da antiguidade que o mundo contemporâneo tem reutilizado, levando a cabo um interessante paralelismo multisecular.

Com "The power of a powerless woman: examining the impact of violence on a Biblical nation”, Elizabeth Tracy nos conduz pelos caminhos da concubina levita, ou Pilegesh, analisando os últimos capítulos do bíblico Livro dos Juízes, cruel em algumas das suas imagens de violência contra a mulher e tão atual, lamentavelmente.

Viajamos depois para a Bretanha na pena da Dra. Tais Pagoto Bélo, com "Britannia: violência, poder e contato", que propõe uma reflexão contemporaneamente válida através da cultura material representada por epitáfios da província da Britannia.

A professora Lorena Lopes da Costa contribui com "Troianas, de Eurípides (415 a. C.): a guerra injusta e o fim da linhagem dos heróis", no qual traça um paralelismo da história de Atenas, dos crimes e excessos da guerra, com a tragédia euripidiana.

Estefanía Bernabé-Sánchez trata o tema da violência sexual em "El mito de Inanna y Šukaletuda: violencia sexual en Sumer", mito no qual a deusa Inanna é estuprada pelo mau jardineiro Šukaletuda. A autora estabelece um paralelismo entre o crime sexual cometido contra a deusa suméria e aqueles que estão sendo, hoje, moeda comum nos conflitos armados do Oriente Médio, especialmente na Síria.

Finalmente, encerra este dossiê o trabalho do professor Fábio Vergara Cerqueira, "Melodia sangrenta' (Anth.Pal. VI.159): a trombeta e a guerra na Grécia Antiga”, em que ele analisa o instrumento de

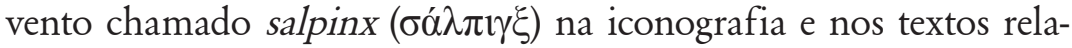
cionados com a guerra na Grécia antiga, particularmente em Atenas, estabelecendo paralelismos entre as funções militares e os simbolismos. 
O intuito deste volume que apresentamos, então, nos convida à reflexão crítica sobre a nossa realidade, partindo do conhecimento da remota antiguidade, de seus personagens e suas histórias, assim como da ideia de que guerra e violência, entendidas em todas as suas manifestações, são nefastas e não atendem aos pressupostos em que a humanidade deve enxergar a evolução e o desenvolvimento.

Frente àqueles que esquecem o passado e, por conseguinte, descuidam do presente enquanto olham para o futuro, anotemos aqui a definição que Sêneca nos deixou em De brevitate vitae (Sobre a brevidade da vida): sábio é aquele que lembra o passado, sabe aproveitar o presente e dispõe do futuro.

Que isso seja como uma de nossas bússolas.

\section{Referências}

MAGNOLI, Demétrio (Org.). História das Guerras. São Paulo: Contexto, 2006. 